\title{
Maternal infections: revisiting the need for screening in pregnancy
}

\author{
Valentine Bardon ${ }^{1}$ and Yves Ville ${ }^{2}$ \\ ${ }^{1}$ Hôpital universitaire Necker-Enfants malades \\ ${ }^{2}$ Universite paris descartes
}

May 12, 2020

\begin{abstract}
The decision to implement screening for infections during pregnancy depends upon epidemiological, economic, therapeutic and test performance criteria. It therefore varies with public health priorities from country to country. When screening is implemented, first trimester has become the best time slot to build individual care pathways also in this field. This is most relevant for evaluating the risk of embryonic consequences, plan diagnostic testing, initiate primary or secondary prevention and increase the accuracy of ultrasound follow-up. This is a critical appraisal of epidemiological data and current international screening recommendations for infections in pregnancy.
\end{abstract}

\section{Maternal infections: revisiting the need for screening in pregnancy}

Valentine Faure-Bardon ${ }^{1,2,{ }^{*}}$, Yves Ville ${ }^{1,2}$

1. EA 73-28, Paris Descartes University, Sorbonne Paris Cité, Paris, 75005, France.

2. AP-HP, Hospital Necker-E.M., Maternity, Paris, 75015, France

*Correspondence:valentine.faure@aphp.fr

Running head : Early Pregnancy Infection Screening

\begin{abstract}
The decision to implement screening for infections during pregnancy depends upon epidemiological, economic, therapeutic and test performance criteria. It therefore varies with public health priorities from country to country.
\end{abstract}

When screening is implemented, first trimester has become the best time slot to build individual care pathways also in this field. This is most relevant for evaluating the risk of embryonic consequences, plan diagnostic testing, initiate primary or secondary prevention and increase the accuracy of ultrasound followup.

This is a critical appraisal of epidemiological data and current international screening recommendations for infections in pregnancy.

\section{Introduction}

The decision to implement screening for infections during pregnancy depends upon epidemiological, economic, therapeutic and test performance criteria. It therefore varies with public health priorities from country to 
country.

When screening is implemented, first trimester has become the best time slot to build individual care pathways also in this field. This is most relevant for evaluating the risk of embryonic consequences, plan diagnostic testing, initiate primary or secondary prevention and increase the accuracy of ultrasound followup.

This is a critical appraisal of epidemiological data and current international screening recommendations for infections in pregnancy.

\section{Pregnancy: an opportune time for women to be screened and receive appropriate care for the mother and the unborn child}

\section{Hepatitis $C$}

Hepatitis $\mathrm{C}$ affects $1 \%$ of the adult population (HCV RNA-positive) ${ }^{1}$ and $0.38 \%$ of live born infants are born from HCV-infected women in the USA ${ }^{1,3}$. The risk of vertical transmission is around $5.8 \%$ and up to $10.8 \%$ when women are co-infected with HIV. In contrast, this risk was negligible in women with HCV antibodies but negative for HCV-RNA ${ }^{2}$. Neither mode of delivery nor breastfeeding seem to affect vertical transmission ${ }^{3}$. However, invasive testing, internal fetal monitoring, and prolonged rupture of membranes have been empirically discouraged in the USA ${ }^{4}$.

International recommendations have long been to offer screening to high risk women only (Table 1). However, since April 2020, the CDC and the American Association for the Study of Liver Diseases (AASLD) ${ }^{5}$ have ruled in favor of universal screening in pregnancy when the prevalence of HCV infection is $>0.1 \%$. This should be done at booking using HCV antibody assay and confirmatory RNA testing for positive serologies.

This is in line with recent epidemiologic and cost-effectiveness evaluations as well as the development of new direct-acting antiviral (DAA) therapy ${ }^{5}$. Infected women should be referred for specialized medical evaluation. DAA is not yet approved for use in pregnancy but when introduced post-partum, it treats infected women and reduces the risk of $\mathrm{HCV}$ transmission to future offspring ${ }^{5,6}$.

\section{Hepatitis $B$}

Up to $6 \%$ of pregnant women are infected with hepatitis B in high-prevalence areas such as Western Pacific and African Regions ${ }^{7}$. In the absence of prophylaxis, hepatitis B is passed to the child at birth from $90 \%$ and $10-20 \%$ of mothers who are both ( $\mathrm{HBsAg}$ ) and (HBeAg)-positive and (HBsAg) positivity alone respectively ${ }^{8,9}$. The risk for the infected neonate to develop chronic infection is 80-90\%. Infected offspring becomes a reservoir for horizontal transmission during the first 5 years of life. ${ }^{7}$ Universal screening in pregnancy is recommended worldwide ${ }^{13}$ and should be repeated in the $3^{\text {rd }}$ trimester in high risk-women (Table 1).

Prophylaxis is obtained through hepatitis B vaccination and hepatitis B immunoglobulin (Ig) administration at birth in neonates born from $\mathrm{HBsAg}$-positive mother.

Antiviral treatment with telbivudine, lamivudine, and tenofovir is safe in pregnancy ${ }^{11,12}$ and is indicated in cases with high viral load (HBV DNA $>200,000 \mathrm{IU} / \mathrm{mL}$ or $10^{6}$ copies $/ \mathrm{mL}$ ). It improves HBV suppression and reduces perinatal transmission $(\mathrm{RR}=0.3)^{11,12}$. This strategy proved cost-effective in the USA ${ }^{13}$. Vaccination remains a goal and can be safely offered to seronegative women in early pregnancy ${ }^{7,10,14}$.

\section{Human Immunodeficiency Virus (HIV)}

Around 1.3 million HIV positive women become pregnant every year ${ }^{15}$ and in the US, 1 in 9 women with HIV are unaware they have it ${ }^{16}$. The highest prevalence of HIV among adults aged 15 to 49 reaches 
$3.9 \%$ in Africas ${ }^{17}$. Perinatal transmission occurs during pregnancy, at delivery, but also in the postpartum period through breastfeeding. Without medical intervention 15-30\% of infants born to HIV-positive women will become infected during gestation and delivery, with a further $5-15 \%$ becoming infected through breastfeeding ${ }^{15}$. Universal screening in pregnancy is recommended although not mandatory in any country for ethical reasons (Table 1). In order to encourage its implementation, some countries opted for systematic screening unless the woman explicitly refuses (opt-out approach) ${ }^{18}$.

The performance of the HIV-1/2 antigen/antibody test is excellent with $99.8 \%$ to $100 \%$ sensitivity and $99.5 \%$ to $100 \%$ specificity and the results are available within hours with rapid HIV-tests ${ }^{19}$. Screening should be carried out as early as possible in pregnancy, at best pre-conceptionally.

In the event of positive serology, immediate initiation of antiretroviral treatment has proven effective to reduce MTCT down to $1.5 \%^{20,21}$ and virtually zero when treatment is initiated before conception ${ }^{22}$. When maternal viral load is significant, planned caesarean section covered by intravenous Zidovudine is recommended across the board. However the viral load threshold above which a planned caesarean section may be beneficial is difficult to establish, which explains the discrepancy between recommendations ranging between $50,<1000$, and $<400$ copies/mL in the British, American and French recommendations respectively ${ }^{23} 2425$.

Finally, serial screening in $1^{\text {st }}$ and $3^{\text {rd }}$ trimesters also benefits high-risk seronegative women to discuss preexposure prophylaxis (PrEP) ${ }^{26}$ to reduce the risk of $\mathrm{MTCT}^{27}$.

\section{Chlamydia trachomatis (ChT)}

$\mathrm{ChT}$ is the most common sexually transmitted pathogen affecting up to $4.3 \%$ of sexually active women in the US and infections are largely asymptomatic ${ }^{28}$. In pregnancy, $1.7 \%$ of mostly asymptomatic women were diagnosed with $\mathrm{ChT}^{29}$.

A review of 614,892 cases suggested that ChT infection in pregnancy increases the odds of several adverse outcomes: preterm premature rupture of membranes $(\mathrm{OR}=1.81)$ endometritis $(\mathrm{OR}=1.69)$ low birthweight $(\mathrm{OR}=1.34)$, small for gestational age $(\mathrm{SGA})(\mathrm{OR}=1.14)$ and intrauterine fetal demise $(\mathrm{OR}=1.44)^{30}$. However, authors highlighted that the literature in this review was complicated by heterogeneity and that the association may not hold in higher quality and prospective studies or those that use more contemporary nucleic acid testing. In the largest recent prospective screening study it was found similar outcomes in women who tested positive and were treated and those who tested negative ${ }^{31}$. Finally, the relationship between ChT infection and miscarriage is unclear ${ }^{29,32}$.

Pregnant women infected with chlamydia can also pass the infection to their infants during delivery. With regard to neonatal consequences, some studies have estimated that $50-70 \%$ of infants born to mothers with ChT will become infected with $\mathrm{ChT}$, and $30-50 \%$ of these infants will then develop chlamydial conjunctivitis, and 10-20\% will develop pneumonia ${ }^{33,34}$.

The evidence for screening and treatment in pregnancy is thin and there is no international consensus on ChT screening in pregnancy and clinical trials are still needed. It is recommended to screen at the first prenatal visit In the US and Canada ${ }^{35}$ but this is seldom in Europe (Table 1) ${ }^{33}$. However, when a vaginal swab shows positive for $\mathrm{ChT}$ in a symptomatic woman, there is a consensus to treat.

\section{Screening for infections that carry a risk of congenital anomaly}

\section{Syphilis}

In 2012, approximately 930,000 maternal syphilis caused 350,000 adverse pregnancy outcomes including 143,000 fetal deaths/stillbirths, 62,000 neonatal deaths, 44,000 preterm/low weight births, and 102,000 infected infants worldwide ${ }^{36}$. Those outcomes were respectively $21 \%, 9.3 \%$ and $5.8 \%$ more frequent than 
among women without syphilis ${ }^{37}$. This led WHO to establish guidelines to prevent vertical transmission, aiming for complete eradication of CS by $2030^{15}$. The CDC raised awareness about the resurgence of cases of congenital syphilis (CS) in the US having more than doubled in 4 years, reaching a 20-year high ${ }^{38}$.

There are two types of serological tests: non-treponemal, (Venereal Diseases Research Laboratory (VDRL); and treponemal (Treponema pallidum haemagglutination assay (TPHA), and fluorescent treponemal antibody absorbed (FTA-ABS) tests). A rapid syphilis treponemal test (RST) is also available with antibody results in 15 minutes. This RST can be performed in any setting without laboratory equipment unlike the other tests. Screening at booking is recommended worldwide for effective maternal treatment and WHO has issued empirical decision-making flowcharts for screening and treatment ${ }^{39}$. Serologic testing is also recommended while exploring cases of intrauterine fetal death ${ }^{38,39}$.

Benzathine penicillin G 2.4 million units is given once intramuscularly in primary, secondary and latent syphilis of not more than two years. This should be repeated weekly for 3 weeks in infections ongoing more two years without evidence of treponemal infection ${ }^{40}$.

Making syphilis screening universal, or even mandatory, may seem excessive, particularly in low prevalence populations, but WHO argues that this should be maintained and reinforced because it increases equity, is cost-effective, acceptable to patients, correctly performed by laboratories and, above all, it prevents severe obstetric complications in the event of proven infection (Table 1).

\section{Toxoplasmosis}

Maternal primary infection (MPI) with Toxoplasma gondii is mostly asymptomatic ${ }^{41}$, but it carries a risk of neurological and ocular sequelae in the offspring. Although congenital toxoplasmosis $(\mathrm{CT})$ poses a substantial burden of poor health with around 190,100 cases worldwide per year ${ }^{42}$, seroprevalence has dropped in many countries over the last 20 years. In French pregnant women, it decreased, from $54 \%$ in 1995 to $37 \%$ in $2010^{43}$ and a similar decrease was observed in the US, down to $9.1 \%{ }^{44}$. In France, the rate of seroconversion during pregnancy was between $0.2 \%$ and $0.25 \%$ in $2015^{45}$ and since 2007 an overall prevalence was estimated around 3 to 4 cases per 10,000 live births (prevalence of severe forms: 0,1 in 10,000). However, $10 \%$ of CT infections are symptomatic, $25 \%$ of those are severe and over $10 \%$ lead to medical terminations of pregnancy following prenatal diagnosis ${ }^{45}$.

Few countries offer routine screening for CT during pregnancy, and France and Austria have been most proactive since the $1970 \mathrm{~s}^{46,47}$ (Table 1). Both programs have witnessed a decline in the incidence of CT and in fetal and pediatric damage ${ }^{48,49}$.

The rationale for not offering screening includes low incidence of the disease, cost of screening and lack of evidence regarding effectiveness of antenatal treatment. However, recent publications from France and Austria suggest that prenatal screening for prevention was cost-saving and led to maintain current policies ${ }^{47,48}$.

Classically, it is assumed that cat and food hygiene and cooking, particularly consumption of rare or raw meat are the main risk factors for infection with toxoplasma ${ }^{50},{ }^{41}$. However, the only two randomized clinical trials (RCT) testing education approaches, showed no difference in seroconversion in relation with any of those risk factors ${ }^{51,52}$.

MPI is the appearance of specific G globulins ( $\operatorname{IgG}$ ) in a previously seronegative patient or by marked elevation of specific $\operatorname{IgG}$ in the presence of specific $\operatorname{Ig}$ M (IgM). The difficulty rests in the interpretation of positive IgM. Indeed, IgM may persist for years following acute infection; therefore isolated positive IgM are not absolute evidence of recent toxoplasmosis ${ }^{53}$. Algorithms of interpretation, using different assays to measure Ig titers, IgG avidity and sequential serological testing should be used to date MPI within expert laboratories ${ }^{47}$.

MTCT is by transplacental passage of the parasite and the rate increases with gestational age at seroconversion $(\mathrm{OR}=1.17 \text { for each additional week })^{54}$. In one meta-analysis the rate of MTCT by gestational age at 
seroconversion was $15 \%, 44 \%, 71 \%$ at $13,26,36$ weeks respectively ${ }^{55}$. The risk of maternal seroconversion in the first weeks of pregnancy is $<5 \%^{56,57}$.

Gestational age at maternal seroconversion is the major prognostic factor in CT. The number of fetuses showing CT-related abnormalities on ultrasound is higher in infections early in pregnancy, and in up to $78 \%$ in the first trimester ${ }^{58}$. The proportion of symptomatic infants before the age of 3 falls from $61 \%$ to $25 \%$ and $9 \%$ following MPI at 13, 26 and 36 weeks respectively ${ }^{59}$.

Infected fetuses can be asymptomatic or bear multisystemic damage including brain injury ${ }^{60}$ and even die in-utero ${ }^{61}$. Normal antenatal ultrasound follow-up is associated, with a negligible risk of abnormal neurological outcome, even following first-trimester infection ${ }^{57,62}$. However normal ultrasound monitoring cannot exclude the risk of chorioretinitis ${ }^{62}$. CT treated prenatally carries an overall risk of chorioretinitis of $26 \%$, although mainly peripheral. ${ }^{57}$. Long-term follow-up is recommended since only $39 \%$ of chorioretinitis are diagnosed at birth ${ }^{57}$.

The rationale for antenatal treatment in $\mathrm{CT}$ is controversial. Treatment regimens vary but are based upon spiramycin and pyrimethamine-sulfamides (PS) (Figure 1) $)^{47,46}$.

None of the recent prospective ${ }^{63}$, or randomized studies ${ }^{54}$ reported a significant effect of antenatal treatment on MTCT or on the fetal prognosis although none could exclude clinical benefits. The SYROCOT study reviewed 26 cohorts with 1,438 cases following prenatal screening and reported that treatment started within 3 weeks of seroconversion reduced MTCT compared with late $\left(>8\right.$ weeks) treatment $(\mathrm{p}=0.05)^{55}$. The EMSCOT study found that prenatal treatment of infected fetuses, adjusted for gestational age at MPI , reduces the risk of serious neurological sequelae by $75 \%{ }^{64}$. In addition, in 300 infants with CT, an interval $>8$ weeks between MPI and intrauterine treatment initiation was associated with an increased risk of chorioretinitis ${ }^{65}$. Finally, in the only RCT comparing the two antenatal drug regimens, the incidence of prenatal cerebral signs of CT following prophylactic administration was lower with PS than with spiramycin 54 .

Although CT can cause severe complications in the fetus, its decline in prevalence and incidence and controversial data on the efficacy of antenatal therapy explain that only a few countries in the world offer screening in pregnancy. However, primary prevention and screening for toxoplasmosis at first prenatal care visit is easy to implement with cost-benefit studies pointing in this direction.

\section{Cytomegalovirus}

Cytomegalovirus is the most common congenital infection (cCMV), affecting $0.5-2 \%$ of live births. It is the main non-genetic cause of congenital sensorineural hearing loss and of neurological damage ${ }^{6667}$. In highincome countries, about half of infected newborns are infected as a result of MPI and the other half as a result of non-MPI (reactivation or re-infection) ${ }^{68}$. Seroprevalence is high $(50 \%$ in the USA and Europe, up to $100 \%$ in southern countries) and women at higher risk for MPI during pregnancy in high-income countries are typically young, multiparous, with high income ${ }^{68}$. In addition, it has recently been shown that women delivering again within 3 years of a previous baby who is in childcare have a $7 \%$ risk of MPI in the first trimester of the new pregnancy ${ }^{69}$.

The risk of MTCT depends upon the trimester of MPI. Summarizing the results of the most relevant studies, it appears that the risk of transmission after MPI in the $1^{\text {st }}, 2^{\text {nd }}$ and $3^{\text {rd }}$ trimester, is $38 \%(158 / 418), 40 \%$ $(107 / 264)$, and $66 \%(78 / 118)$ respectively ${ }^{70-73}$.

Following MPI, only first-trimester infections can lead to sequelae ${ }^{74,75}$. In the natural history, approximately $30-35 \%$ of newborns infected after first-trimester infection develop neurological sequelae, and $25 \%$ suffer hearing loss, mostly unilateral ${ }^{76}$.

Despite the high burden of cCMV infection, , screening for MPI during pregnancy is not recommended by any public health authority but Germany ${ }^{77,78}$. This is due to older concerns about sensitivity and specificity 
of serological tests, difficulty in establishing the prognosis of an infected fetus, and the lack of validated prenatal treatment options ${ }^{79}$. However, some issues need an update:

First, MPI is reliably identified by serologic testing based on IgG and IgM followed by IgG avidity testing in IgM positive cases. Low CMV IgG avidity indicates MPI within the preceding 3-4 months. Sensitivity and specificity of this algorithm depends mainly on the performance of the IgM kits used, the accuracy of the "low" range of IgG values, and the timing of serology screening 80,81

Secondly, the prognosis of fetal infection relies upon standardized prenatal assessment ${ }^{82}$. Although gestational age at infection is a major prognostic factor ${ }^{75,76,83}$, other parameters including sequential ultrasound (US) examinations in second and third trimesters, platelet count in fetal blood, and prenatal Magnetic Resonance Imaging (MRI) have all been shown to independently predict the outcome of infected fetuses in different studies ${ }^{70,84-89}$. The combination of ultrasound and MRI has a negative predictive value of 95 to $99 \% 82,83,90$.

Finally, the first indication of antivirals in fetal cCMV infection was to reduce the risk of sequelae in a fetus with proven fetal infection. In a phase II open-label trial, oral valaciclovir $(8 \mathrm{~g} / \mathrm{d})$ given in pregnancies with mildly symptomatic fetuses was associated with a higher chance of delivering an asymptomatic neonate (82\%), compared with an untreated historical cohort $(43 \%)^{91}$. CMV-hyperimmune globulins did not prove to be effective in this indication ${ }^{92}$. The focus has recently addressed the efficacy of secondary prevention by giving treatment as soon as MPI is biologically proven in the first trimester in order to reduce the risk of MTCT and therefore the risk of sequelae. In a randomized double-blind, placebo-controlled study , Valaciclovir at a dose of $8 \mathrm{~g}$ /day reduced the rate of fetal infection by $71 \%^{93}$. CMV-hyperimmune globulins have been studied in this indication and there was a statistically significant difference when compared to untreated historical cohorts ${ }^{94}$ (MTCT $=2.5 \%$ vs $35.2 \%$ in the treatment and historical groups respectively). However, this could not be shown through RCT including cases up to 28 weeks' which may have decreased the impact of hyperimmune globulins ${ }^{92}$.

Maternal screening in early pregnancy would also benefit seronegative women, since individual primary prevention measures in these women have proven to be effective in significantly preventing MPI.

The recent and solid data highlighting 1) the typical profile of the pregnant women at risk of MPI, 2) the first trimester of pregnancy as the only one at risk of sequelae 3) the reduction of MTCT with antenatal valaciclovir, bring new perspectives for implementation of screening in early pregnancy.

\section{Rubella}

Rubella is a leading vaccine-preventable cause of birth defects since the early 1970s. Before the introduction of the vaccine, up to 4 babies per 1,000 live births were born with congenital rubella syndrome (CRS), an often devastating condition ${ }^{95}$. This includes low birth weight, deafness, mental retardation, cardiac and eye malformations ${ }^{96,97}$. The risk of MTCT is $80-90 \%, 54 \%$ and $25 \%$ when maternal rash occurs before 12 , at 13-14 and after 20 weeks of pregnancy respectively ${ }^{95,98} .98$. The risk of sequelae is constant before 12 weeks and nil after 16 weeks; in-between, a third of the fetuses develop sequelae, particularly deafness ${ }^{96,98}$.

In 2015, the WHO Region of the Americas became the first in the world to be declared free of endemic transmission of rubella ${ }^{103}$ whereas CRS rates are highest in the WHO African and South-East Asian regions where vaccination coverage is lowest. However, even in countries where endemic virus has disappeared, cases emerge, mainly due to non-immune migratory human flows ${ }^{97,99},{ }^{100}$. Screening with rubella specific antibodies during pregnancy is not/no longer recommended in some industrialized countries such as the United Kingdom or the US. It remains mandatory in France (Table 1).

The search for proof of immunity at the very beginning of pregnancy seems essential both to set up primary prevention measures and, above all, to consider vaccination after delivery, even before discharge from maternity ward. 


\section{Varicella}

The incidence of varicella zoster virus (VZV) infection in pregnancy is around 1.2/10,000 ${ }^{101}$ and the MTCT is $25 \%{ }^{102}$. Sequelae have only been observed in $2 \%$ of infected fetuses and only before 20 weeks ${ }^{103}$. The damage is ubiquitous including IUGR, skin lesions, neurological, eye, skeletal, gastrointestinal and genitourinary anomalies ${ }^{104}$. Maternal VZV infection also carries a risk of severe neonatal varicella in an estimated $17 \%-30 \%$ when it occurs between $\mathrm{d}-5$ and $\mathrm{d}+2$ relative to the date of delivery ${ }^{105}$. Non-immune pregnant women exposed to VZV (household contact, face-to-face contact $>5$ minutes or in the same room > 1 hour) should receive post-exposure prophylaxis with anti-VZV-immunoglobulins, ideally within 96 hours, and no later than 10 days after infection ${ }^{105}$. The effect of this therapy has mostly been studied in order to reduce the risk of maternal morbidity that exists in case of MPI. The live attenuated VZV vaccine is contraindicated in pregnant women. Care givers should enquire about the immunological status of pregnant women for VZV (personal history of chickenpox, vaccination, or serology if in doubt) to prevent from exposing themselves to a situation as trivial as a child who has chickenpox in the first part of their pregnancy.

\section{Conclusion}

Infections during pregnancy can impact the prognosis of the fetus, the newborn and the infant. Young healthy pregnant women are often not aware of those risks, and first prenatal care visit is a key time slot in the obstetrical calendar to also raise those issues. Hepatitis B and C, HIV, genital Chlamydia infection are not rare diseases and should no longer be suspected only in precarious or marginal populations. Vertical transmission of these infections, from women who do not know they are carriers, maintains a significant incidence of chronic diseases.

Rubella, syphilis, VZV, Toxoplasma Gondii and CMV infections can lead to severe birth defects, especially when the fetus is in contact with the pathogen in early pregnancy. These infections are preventable by primary prevention measures implemented early enough. The WHO criteria validating the implementation of screening may not all strictly be met for these infections. However, the duty to provide accurate information, which frequently goes hand in hand with the maternal request to search for immunity, is in agreement with the principles of benevolence and non-malevolence guiding our practice.

\section{Disclosure of Interests}

Valentine Faure-Bardon has no disclosures.

Yves Ville reports non-financial support from Ferring SAS, non-financial support from Siemens health Care, non-financial support from GE medical, outside the submitted work .

\section{Contribution to Authorship}

YV and VFB designed and wrote the paper.

\section{Details of ethics approval}

Not required

\section{Funding}

No funding source was necessary for this work 


\section{References}

1. Hofmeister MG, Rosenthal EM, Barker LK, Rosenberg ES, Barranco MA, Hall EW, et al. Estimating Prevalence of Hepatitis C Virus Infection in the United States, 2013-2016. Hepatology [Internet]. 2019 Mar 1 [cited 2020 Apr 19];69(3):1020-31. Available from: https://aasldpubs-onlinelibrary-wileycom.sirius.parisdescartes.fr/doi/full/10.1002/hep.30297

2. Benova L, Mohamoud YA, Calvert C, Abu-Raddad LJ. Vertical Transmission of Hepatitis C Virus: Systematic Review and Meta-analysis. Clin Infect Dis [Internet]. 2014 Sep 15 [cited 2020 Apr 19];59(6):76573. Available from: https://academic-oup-com.sirius.parisdescartes.fr/cid/article/59/6/765/2895673

3. Cottrell EB, Chou R, Wasson N, Rahman B, Guise J-M. Reducing Risk for Mother-to-Infant Transmission of Hepatitis C Virus: A Systematic Review for the U.S. Preventive Services Task Force. Ann Intern Med [Internet]. 2013 Jan 15 [cited 2020 Apr 19];158(2):109. Available from: http://annals.org/article.aspx?doi=10.7326/0003-4819-158-2-201301150-00575

4. Hughes BL, Page CM, Kuller JA. Hepatitis C in pregnancy: screening, treatment, and management. Am J Obstet Gynecol [Internet]. 2017 Nov 1 [cited 2020 Apr 19];217(5):B2-12. Available from: http://www.sciencedirect.com/science/article/pii/S0002937817309304

5. AASLD-IDSA HCV Guidance Panel. Hepatitis C Guidance 2018 Update: AASLD-IDSA Recommendations for Testing, Managing, and Treating Hepatitis C Virus Infection. Clin Infect Dis [Internet]. 2018 Sep 12 [cited 2020 Apr 20];67(10):1477-92. Available from: https://doi.org/10.1093/cid/ciy585

6. Schillie S. CDC Recommendations for Hepatitis C Screening Among Adults - United States, 2020. MMWR Recomm Rep [Internet]. 2020 [cited 2020 Apr 12];69. Available from: https://www.cdc.gov/mmwr/volumes/69/rr/rr6902a1.htm

7. Hepatitis B [Internet]. [cited 2020 Apr 20]. Available from: https://www.who.int/news-room/factsheets/detail/hepatitis-b

8. Bartholomew ML, Lee M-J. Management of Hepatitis B Infection in Pregnancy. Clin Obstet Gynecol [Internet]. 2018 Mar [cited 2020 Apr 22];61(1):137-145. Available from: http://journals.lww.com/clinicalobgyn/fulltext/2018/03000/Management_of_Hepatitis_B_Infection_in_Pregnancy.16.aspx

9. Viral Hepatitis in Pregnancy [Internet]. [cited 2020 Apr 13]. Available from: https://www.acog.org/en/Clinical/Clinical Guidance/Practice Bulletin/Articles/2007/10/Viral Hepatitis in Pregnancy

10. Prabhu M, Riley LE. Universal Screening and Vaccination for Hepatitis B in Pregnancy: The Time Is Now. Obstet Gynecol [Internet]. 2020 Apr [cited 2020 Apr 22];135(4):808-811. Available from: http://journals.lww.com/greenjournal/Abstract/2020/04000/Universal_Screening_and_Vaccination_for_Hepatitis.8.aspx

11. Brown Jr. RS, McMahon BJ, Lok ASF, Wong JB, Ahmed AT, Mouchli MA, et al. Antiviral therapy in chronic hepatitis B viral infection during pregnancy: A systematic review and meta-analysis. Hepatology [Internet]. 2016 Jan 1 [cited 2020 Apr 22];63(1):319-33. Available from: https://aasldpubs-onlinelibrarywiley-com.sirius.parisdescartes.fr/doi/full/10.1002/hep.28302

12. Terrault NA, Bzowej NH, Chang K-M, Hwang JP, Jonas MM, Murad MH. AASLD guidelines for treatment of chronic hepatitis B. Hepatology [Internet]. 2016 Jan 1 [cited 2020 Apr 22];63(1):261-83. Available from: https://aasldpubs-onlinelibrary-wiley-com.sirius.parisdescartes.fr/doi/full/10.1002/hep.28156

13. Fan L, Owusu-Edusei Jr. K, Schillie SF, Murphy TV. Cost-effectiveness of active-passive prophylaxis and antiviral prophylaxis during pregnancy to prevent perinatal hepatitis B virus infection. Hepatology [Internet]. 2016 May 1 [cited 2020 Apr 22];63(5):1471-80. Available from: https://aasldpubs-onlinelibrarywiley-com.sirius.parisdescartes.fr/doi/full/10.1002/hep.28310 
14. Zhao H, Zhou X, Zhou Y-H. Hepatitis B vaccine development and implementation. Hum Vaccines Immunother [Internet]. 2020 Mar 18 [cited 2020 Apr 22];0(0):1-12. Available from: https://doi.org/10.1080/21645515.2020.1732166

15. WHO | Global guidance on criteria and processes for validation: Elimination of Motherto-Child Transmission of HIV and Syphilis [Internet]. [cited 2020 Apr 25]. Available from: https://www.who.int/reproductivehealth/publications/emtct-hiv-syphilis/en/

16. Women | Gender | HIV by Group | HIV/AIDS | CDC [Internet]. 2020 [cited 2020 Apr 25]. Available from: https://www.cdc.gov/hiv/group/gender/women/index.html

17. GHO | By category | Prevalence of HIV among adults aged 15 to 49 - Estimates by WHO region [Internet]. WHO. World Health Organization; [cited 2020 Apr 25]. Available from: https://apps.who.int/gho/data/view.main.22500WHOREG?lang=en

18. Gebrezgi MT, Mauck DE, Sheehan DM, Fennie KP, Cyrus E, Degarege A, et al. Acceptance of Opt-Out HIV Screening in Outpatient Settings in the United States: A Systematic Review and MetaAnalysis. Public Health Rep [Internet]. 2019 Sep 1 [cited 2020 Apr 25];134(5):484-92. Available from: https://doi.org/10.1177/0033354919860510

19. Centers for Disease Control and Prevention (U.S.), Bernard M. B, Association of Public Health Laboratorie, S. Michele O, Laura G. W, Berry B, et al. Laboratory testing for the diagnosis of HIV infection : updated recommendations [Internet]. Centers for Disease Control and Prevention; 2014 Jun [cited 2020 Apr 25]. Available from: http://stacks.cdc.gov/view/cdc/23447

20. Dorenbaum A, Cunningham CK, Gelber RD, Culnane M, Mofenson L, Britto P, et al. Two-Dose Intrapartum/Newborn Nevirapine and Standard Antiretroviral Therapy to Reduce Perinatal HIV Transmission: A Randomized Trial. JAMA [Internet]. 2002 Jul 10 [cited 2020 Apr 25];288(2):189-98. Available from: https://jamanetwork-com.sirius.parisdescartes.fr/journals/jama/fullarticle/195097

21. Warszawski J, Tubiana R, Le Chenadec J, Blanche S, Teglas J-P, Dollfus C, et al. Mother-to-child HIV transmission despite antiretroviral therapy in the ANRS French Perinatal Cohort. AIDS Lond Engl. 2008 Jan 11;22(2):289-99.

22. Mandelbrot L, Tubiana R, Le Chenadec J, Dollfus C, Faye A, Pannier E, et al. No Perinatal HIV-1 Transmission From Women With Effective Antiretroviral Therapy Starting Before Conception. Clin Infect Dis Off Publ Infect Dis Soc Am. 2015 Dec 1;61(11):1715-25.

23. HIV in Pregnancy, Management (Green-top Guideline No. 39) [Internet]. [cited 2020 Apr 25]. Available from: https://webcache.googleusercontent.com/search?q=cache:4ukFSgy64SYJ:https://www.rcog.org.uk/en/guidelinesresearch-services/guidelines/gtg39/+\&cd=1\&hl=fr\&ct=clnk\&gl=fr\&client=safari

24. Labor and Delivery Management of Women With Human Immunodeficiency Virus Infection [Internet]. [cited 2020 Apr 25]. Available from: https://www.acog.org/en/Clinical/Clinical Guidance/Committee Opinion/Articles/2018/09/Labor and Delivery Management of Women With Human Immunodeficiency Virus Infection

25. Blanc A, Bonnet F, Brun-Vezinet F, Costagliola D, Dabis F, Delobel P, et al. Groupe d'experts pour la prise en charge du VIH. 2018;52.

26. Dettinger JC, Kinuthia J, Pintye J, Mwongeli N, Gomez L, Richardson BA, et al. PrEP Implementation for Mothers in Antenatal Care (PrIMA): study protocol of a cluster randomised trial. BMJ Open [Internet]. 2019 Mar 1 [cited 2020 Apr 23];9(3):e025122. Available from: https://bmjopen-bmjcom.sirius.parisdescartes.fr/content/9/3/e025122

27. ACOG Committee Opinion No. 752: Prenatal and Perinatal Human Immunodeficiency Virus Testing. Obstet Gynecol [Internet]. 2018 Sep [cited 2020 Apr 13];132(3):e138. Available 
from: https://journals.lww.com/greenjournal/fulltext/2018/09000/ACOG_Committee_Opinion_No__752_-Prenatal_and.70.aspx

28. Chlamydia - 2018 Sexually Transmitted Diseases Surveillance [Internet]. 2019 [cited 2020 Apr 25]. Available from: https://www.cdc.gov/std/stats18/chlamydia.htm

29. Reid F, Oakeshott P, Kerry SR, Hay PE, Jensen JS. Chlamydia related bacteria (Chlamydiales) in early pregnancy: community-based cohort study. Clin Microbiol Infect Off Publ Eur Soc Clin Microbiol Infect Dis. 2017 Feb;23(2):119.e9-119.e14.

30. Olson-Chen C, Balaram K, Hackney DN. Chlamydia trachomatis and Adverse Pregnancy Outcomes: Meta-analysis of Patients With and Without Infection. Matern Child Health J. 2018;22(6):812-21.

31. Reekie J, Roberts C, Preen D, Hocking JS, Donovan B, Ward J, et al. Chlamydia trachomatis and the risk of spontaneous preterm birth, babies who are born small for gestational age, and stillbirth: a population-based cohort study. Lancet Infect Dis. 2018;18(4):452-60.

32. Baud D, Greub G. Intracellular bacteria and adverse pregnancy outcomes. Clin Microbiol Infect [Internet]. 2011 Sep 1 [cited 2020 Apr 25];17(9):1312-22. Available from: https://doi.org/10.1111/j.14690691.2011.03604.x

33. Joseph Davey D, Medline A, Klausner J. Screening pregnant women in the 2015 European guideline on the management of Chlamydia trachomatis infections. Int J STD AIDS [Internet]. 2016 Oct 1 [cited 2020 Apr 25];27(12):1134-6. Available from: https://doi.org/10.1177/0956462416650600

34. Schachter J, Grossman M, Sweet RL, Holt J, Jordan C, Bishop E. Prospective study of perinatal transmission of Chlamydia trachomatis. JAMA. 1986 Jun 27;255(24):3374-7.

35. Canada PHA of. Section 5-2: Canadian Guidelines on Sexually Transmitted Infections - Management and treatment of specific infections - Chlamydial Infections [Internet]. aem. 2013 [cited 2020 Apr 25]. Available from: https://www.canada.ca/en/public-health/services/infectious-diseases/sexual-healthsexually-transmitted-infections/canadian-guidelines/sexually-transmitted-infections/canadian-guidelinessexually-transmitted-infections-30.html

36. Wijesooriya NS, Rochat RW, Kamb ML, Turlapati P, Temmerman M, Broutet N, et al. Global burden of maternal and congenital syphilis in 2008 and 2012: a health systems modelling study. Lancet Glob Health [Internet]. 2016 Aug 1 [cited 2020 Apr 26];4(8):e525-33. Available from: http://www.sciencedirect.com/science/article/pii/S2214109X16301358

37. Untreated maternal syphilis and adverse outcomes of pregnancy: a systematic review and meta-analysis [Internet]. [cited 2020 Apr 26]. Available from: https://www-ncbi-nlm-nihgov.sirius.parisdescartes.fr/pmc/articles/PMC3590617/

38. A Devastating Surge in Congenital Syphilis: How Can We Stop It? [Internet]. Medscape. [cited 2020 Apr 25]. Available from: http://www.medscape.com/viewarticle/907183

39. WHO | WHO guideline on syphilis screening and treatment for pregnant women [Internet]. WHO. World Health Organization; [cited 2020 Apr 26]. Available from: http://www.who.int/reproductivehealth/publications/rtis/syphilis-ANC-screenandtreat-guidelines/en/

40. World Health Organization. WHO guidelines for the treatment of treponema pallidum (Syphilis). [Internet]. 2016 [cited 2020 Apr 26]. Available from: http://www.ncbi.nlm.nih.gov/books/NBK384904/

41. Preventing Congenital Toxoplasmosis [Internet]. [cited 2020 Feb 22]. Available from: https://www.cdc.gov/mmwr/preview/mmwrhtml/rr4902a5.htm

42. Torgerson PR, Mastroiacovo P. The global burden of congenital toxoplasmosis: a systematic review. Bull World Health Organ [Internet]. 2013 Jul 1 [cited 2020 Feb 24];91(7):501. Available from: https://wwwncbi-nlm-nih-gov.sirius.parisdescartes.fr/pmc/articles/PMC3699792/ 
43. Article - Bulletin epidemiologique hebdomadaire [Internet]. [cited 2020 Feb 26]. Available from: http://beh.santepubliquefrance.fr/beh/2015/15-16/2015_15-16_5.html

44. Price C, Wilkins PP, Kruszon-Moran D, Jones JL, Rivera HN. Toxoplasma gondii Seroprevalence in the United States 2009-2010 and Comparison with the Past Two Decades. Am J Trop Med Hyg [Internet]. 2014 Jun 4 [cited 2020 Feb 26];90(6):1135-9. Available from: http://www.ajtmh.org/content/journals/10.4269/ajtmh.14-0013

45. Diagnostic biologique de la toxoplasmose acquise du sujet immunocompetent (dont la femme enceinte), la toxoplasmose congenitale (diagnostic pre- et postnatal) et la toxoplasmose oculaire [Internet]. Haute Autorite de Sante. [cited 2020 Feb 24]. Available from: https://www.has-sante.fr/jcms/c_2653655 /fr/diagnostic-biologique-de-la-toxoplasmose-acquise-du-sujet-immunocompetent-dont-la-femmeenceinte-la-toxoplasmose-congenitale-diagnostic-pre-et-postnatal-et-la-toxoplasmose-oculaire

46. Prusa A-R, Kasper DC, Pollak A, Gleiss A, Waldhoer T, Hayde M. The Austrian Toxoplasmosis Register, 1992-2008. Clin Infect Dis [Internet]. 2015 Jan 15 [cited 2020 Feb 24];60(2):e4-10. Available from: https://academic-oup-com.sirius.parisdescartes.fr/cid/article/60/2/e4/2895402

47. Peyron F, L'ollivier C, Mandelbrot L, Wallon M, Piarroux R, Kieffer F, et al. Maternal and Congenital Toxoplasmosis: Diagnosis and Treatment Recommendations of a French Multidisciplinary Working Group. Pathogens [Internet]. 2019 Mar [cited 2020 Feb 24];8(1):24. Available from: https://www.mdpi.com/2076$0817 / 8 / 1 / 24$

48. Congenital toxoplasmosis in Austria: Prenatal screening for prevention is cost-saving [Internet]. [cited 2020 Feb 19]. Available from: https://journals.plos.org/plosntds/article?id=10.1371/journal.pntd.0005648

49. Wallon M, Peyron F, Cornu C, Vinault S, Abrahamowicz M, Kopp CB, et al. Congenital Toxoplasma Infection: Monthly Prenatal Screening Decreases Transmission Rate and Improves Clinical Outcome at Age 3 Years. Clin Infect Dis [Internet]. 2013 May 1 [cited 2020 Feb 24];56(9):1223-31. Available from: https://academic-oup-com.sirius.parisdescartes.fr/cid/article/56/9/1223/293975

50. Cook AJC, Holliman R, Gilbert RE, Buffolano W, Zufferey J, Petersen E, et al. Sources of toxoplasma infection in pregnant women: European multicentre case-control studyCommentary: Congenital toxoplasmosis - further thought for food. BMJ [Internet]. $2000 \mathrm{Jul} 15$ [cited 2020 Feb 24];321(7254):142-7. Available from: https://www-bmj-com.sirius.parisdescartes.fr/content/321/7254/142

51. Gollub EL, Leroy V, Gilbert R, Chene G, Wallon M. Effectiveness of health education on Toxoplasma-related knowledge, behaviour, and risk of seroconversion in pregnancy. Eur J Obstet Gynecol Reprod Biol [Internet]. 2008 Feb 1 [cited 2020 Feb 22];136(2):137-45. Available from: http://www.sciencedirect.com/science/article/pii/S0301211507004307

52. The effectiveness of a prenatal education programme for the prevention of congenital toxoplasmosis. - PubMed - NCBI [Internet]. [cited 2020 Feb 22]. Available from: https://www-ncbi-nlm-nihgov.sirius.parisdescartes.fr/pubmed/2606162

53. Goldstein EJC, Montoya JG, Remington JS. Management of Toxoplasma gondii Infection during Pregnancy. Clin Infect Dis [Internet]. 2008 Aug 15 [cited 2020 Feb 24];47(4):554-66. Available from: https://academic-oup-com.sirius.parisdescartes.fr/cid/article/47/4/554/304753

54. Mandelbrot L, Kieffer F, Sitta R, Laurichesse-Delmas H, Winer N, Mesnard L, et al. Prenatal therapy with pyrimethamine + sulfadiazine vs spiramycin to reduce placental transmission of toxoplasmosis: a multicenter, randomized trial. Am J Obstet Gynecol [Internet]. 2018 Oct 1 [cited 2020 Feb 22];219(4):386.e1386.e9. Available from: http://www.sciencedirect.com/science/article/pii/S0002937818304411

55. Effectiveness of prenatal treatment for congenital toxoplasmosis: a meta-analysis of individual patients' data. The Lancet [Internet]. 2007 Jan 13 [cited 2020 Feb 19];369(9556):115-22. Available from: http://www.sciencedirect.com/science/article/pii/S0140673607600725 
56. Rabilloud M, Wallon M, Peyron F. In Utero and at Birth Diagnosis of Congenital Toxoplasmosis: Use of Likelihood Ratios for Clinical Management. Pediatr Infect Dis J [Internet]. 2010 May [cited 2020 Feb 24];29(5):421-425. Available from: http://journals.lww.com/pidj/Abstract/2010/05000/In_Utero_and_at_Birth_Diagnosis_of_Congenital.9.aspx

57. Berrebi A, Assouline C, Bessieres M-H, Lathiere M, Cassaing S, Minville V, et al. Long-term outcome of children with congenital toxoplasmosis. Am J Obstet Gynecol [Internet]. 2010 Dec 1 [cited 2020 Feb 22];203(6):552.e1-552.e6. Available from: http://www.sciencedirect.com/science/article/pii/S0002937810007027

58. Hohlfeld P, MacAleese J, Capella-Pavlovski M, Giovangrandi Y, Thulliez P, Forestier F, et al. Fetal toxoplasmosis: ultrasonographic signs. Ultrasound Obstet Gynecol [Internet]. 1991 Jul 1 [cited 2020 Feb 22];1(4):241-4. Available from: https://obgyn-onlinelibrary-wileycom.sirius.parisdescartes.fr/doi/abs/10.1046/j.1469-0705.1991.01040241.x

59. Dunn D, Wallon M, Peyron F, Petersen E, Peckham C, Gilbert R. Mother-to-child transmission of toxoplasmosis: risk estimates for clinical counselling. THE LANCET. 1999;353:5.

60. Malinger G, Werner H, Rodriguez Leonel JC, Rebolledo M, Duque M, Mizyrycki S, et al. Prenatal brain imaging in congenital toxoplasmosis. Prenat Diagn [Internet]. 2011 Sep 1 [cited 2020 Feb 22];31(9):881-6. Available from: https://obgyn-onlinelibrary-wiley-com.sirius.parisdescartes.fr/doi/full/10.1002/pd.2795

61. Desmonts G, Couvreur J. Congenital Toxoplasmosis. N Engl J Med [Internet]. 1974 May 16 [cited 2020 Feb 24];290(20):1110-6. Available from: https://doi.org/10.1056/NEJM197405162902003

62. Berrebi A, Bardou M, Bessieres M-H, Nowakowska D, Castagno R, Rolland M, et al. Outcome for children infected with congenital toxoplasmosis in the first trimester and with normal ultrasound findings: A study of 36 cases. Eur J Obstet Gynecol Reprod Biol [Internet]. 2007 Nov 1 [cited 2020 Feb 22];135(1):53-7. Available from: http://www.sciencedirect.com/science/article/pii/S0301211506006336

63. European Multicentre Study on Congenital Toxoplasmosis, Participants are listed on page 119. Effect of timing and type of treatment on the risk of mother to child transmission of Toxoplasma gondii. BJOG Int J Obstet Gynaecol [Internet]. 2003 Feb 1 [cited 2020 Feb 26];110(2):112-20. Available from: https://obgynonlinelibrary-wiley-com.sirius.parisdescartes.fr/doi/full/10.1046/j.1471-0528.2003.02325.x

64. Cortina-Borja M, Tan HK, Wallon M, Paul M, Prusa A, Buffolano W, et al. Prenatal Treatment for Serious Neurological Sequelae of Congenital Toxoplasmosis: An Observational Prospective Cohort Study. PLOS Med [Internet]. 2010 Oct 12 [cited 2020 Apr 26];7(10):e1000351. Available from: https://journals.plos.org/plosmedicine/article?id=10.1371/journal.pmed.1000351

65. Kieffer F, Wallon M, Garcia P, Thulliez P, Peyron F, Franck J. Risk Factors for Retinochoroiditis During the First 2 Years of Life in Infants With Treated Congenital Toxoplasmosis. Pediatr Infect Dis J [Internet]. 2008 Jan [cited 2020 Feb 26];27(1):27-32. Available from: http://journals.lww.com/pidj/Fulltext/2008/01000/Risk_Factors_for_Retinochoroiditis_During_the.6.aspx

66. Kenneson A, Cannon MJ. Review and meta-analysis of the epidemiology of congenital cytomegalovirus (CMV) infection. Rev Med Virol [Internet]. 2007 Jul [cited 2016 Aug 5];17(4):253-76. Available from: http://doi.wiley.com/10.1002/rmv.535

67. Leruez-Ville M, Foulon I, Pass R, Ville Y. Cytomegalovirus infection during pregnancy: state of the science. Am J Obstet Gynecol [Internet]. 2020 Feb 24 [cited 2020 Apr 27]; Available from: http://www.sciencedirect.com/science/article/pii/S0002937820301988

68. Leruez-Ville M, Magny J-F, Couderc S, Pichon C, Parodi M, Bussieres L, et al. Risk Factors for Congenital Cytomegalovirus Infection Following Primary and Nonprimary Maternal Infection: A Prospective Neonatal Screening Study Using Polymerase Chain Reaction in Saliva. Clin Infect Dis Off Publ Infect Dis Soc Am. 2017 Aug 1;65(3):398-404. 
69. Leruez-Ville M, Guilleminot T, Stirnemann J, Salomon LJ, Spaggiari E, Faure-Bardon V, et al. Quantifying the Burden of Congenital Cytomegalovirus Infection With Long-term Sequelae in Subsequent Pregnancies of Women Seronegative at Their First Pregnancy. Clin Infect Dis [Internet]. [cited 2019 Dec 9]; Available from: https://academic-oup-com.sirius.parisdescartes.fr/cid/advancearticle/doi/10.1093/cid/ciz1067/5610250

70. Picone O, Vauloup-Fellous C, Cordier AG, Guitton S, Senat MV, Fuchs F, et al. A series of 238 cytomegalovirus primary infections during pregnancy: description and outcome. Prenat Diagn. 2013 Aug;33(8):751-8.

71. Revello MG, Fabbri E, Furione M, Zavattoni M, Lilleri D, Tassis B, et al. Role of prenatal diagnosis and counseling in the management of 735 pregnancies complicated by primary human cytomegalovirus infection: a 20-year experience. J Clin Virol Off Publ Pan Am Soc Clin Virol. 2011 Apr;50(4):303-7.

72. Enders G, Daiminger A, Bader U, Exler S, Enders M. Intrauterine transmission and clinical outcome of 248 pregnancies with primary cytomegalovirus infection in relation to gestational age. J Clin Virol Off Publ Pan Am Soc Clin Virol. 2011 Nov;52(3):244-6.

73. Gindes L, Teperberg-Oikawa M, Sherman D, Pardo J, Rahav G. Congenital cytomegalovirus infection following primary maternal infection in the third trimester. BJOG Int J Obstet Gynaecol. 2008 Jun;115(7):830-5.

74. Foulon I, De Brucker Y, Buyl R, Lichtert E, Verbruggen K, Pierard D, et al. Hearing Loss With Congenital Cytomegalovirus Infection. Pediatrics [Internet]. 2019 Aug 1;144(2):e20183095. Available from: http://pediatrics.aappublications.org/content/144/2/e20183095.abstract

75. Faure-Bardon V, Magny J-F, Parodi M, Couderc S, Garcia P, Maillotte A-M, et al. Sequelae of congenital cytomegalovirus (cCMV) following maternal primary infection are limited to those acquired in the first trimester of pregnancy. Clin Infect Dis Off Publ Infect Dis Soc Am. 2018 Dec 31;

76. Pass RF, Fowler KB, Boppana SB, Britt WJ, Stagno S. Congenital cytomegalovirus infection following first trimester maternal infection: symptoms at birth and outcome. J Clin Virol Off Publ Pan Am Soc Clin Virol. 2006 Feb;35(2):216-20.

77. Society for Maternal-Fetal Medicine (SMFM), Hughes BL, Gyamfi-Bannerman C. Diagnosis and antenatal management of congenital cytomegalovirus infection. Am J Obstet Gynecol. 2016 Jun;214(6):B5-11.

78. Rawlinson WD, Boppana SB, Fowler KB, Kimberlin DW, Lazzarotto T, Alain S, et al. Congenital cytomegalovirus infection in pregnancy and the neonate: consensus recommendations for prevention, diagnosis, and therapy. Lancet Infect Dis [Internet]. 2017 Jun 1 [cited 2020 Apr 27];17(6):e177-88. Available from: http://www.sciencedirect.com/science/article/pii/S1473309917301433

79. Cytomegalovirus (CMV) for Healthcare Providers | CDC [Internet]. 2019 [cited 2020 Apr 27]. Available from: https://www.cdc.gov/cmv/clinical/index.html

80. Prince HE, Lape-Nixon M. Role of cytomegalovirus (CMV) IgG avidity testing in diagnosing primary CMV infection during pregnancy. Clin Vaccine Immunol CVI. 2014 Oct;21(10):1377-84.

81. Leruez-Ville M, Sellier Y, Salomon LJ, Stirnemann JJ, Jacquemard F, Ville Y. Prediction of Fetal Infection in Cases With Cytomegalovirus Immunoglobulin M in the First Trimester of Pregnancy: A Retrospective Cohort. Clin Infect Dis [Internet]. 2013 May 15 [cited 2020 Apr 27];56(10):1428-35. Available from: https://academic-oup-com.sirius.parisdescartes.fr/cid/article/56/10/1428/404193

82. Faure-Bardon V, Millischer A-E, Deloison B, Sonigo P, Grevent D, Salomon L, et al. Refining the prognosis of fetuses infected with Cytomegalovirus in the first trimester of pregnancy by serial prenatal assessment: a single-centre retrospective study. BJOG Int J Obstet Gynaecol [Internet]. 2019 Sep 10 [cited 2019 Dec 11];n/a(n/a). Available from: https://obgyn-onlinelibrary-wileycom.sirius.parisdescartes.fr/doi/full/10.1111/1471-0528.15935 
83. Lipitz S, Yinon Y, Malinger G, Yagel S, Levit L, Hoffman C, et al. Risk of cytomegalovirus-associated sequelae in relation to time of infection and findings on prenatal imaging. Ultrasound Obstet Gynecol Off $\mathrm{J}$ Int Soc Ultrasound Obstet Gynecol. 2013 May;41(5):508-14.

84. Guerra B, Simonazzi G, Puccetti C, Lanari M, Farina A, Lazzarotto T, et al. Ultrasound prediction of symptomatic congenital cytomegalovirus infection. Am J Obstet Gynecol [Internet]. 2008 Apr [cited 2017 Jun 5];198(4):380.e1-380.e7. Available from: http://www.sciencedirect.com/science/article/pii/S0002937807011969

85. Cannie MM, Devlieger R, Leyder M, Claus F, Leus A, De Catte L, et al. Congenital cytomegalovirus infection: contribution and best timing of prenatal MR imaging. Eur Radiol. 2016 Mar 17;

86. Doneda C, Parazzini C, Righini A, Rustico M, Tassis B, Fabbri E, et al. Early cerebral lesions in cytomegalovirus infection: prenatal MR imaging. Radiology. 2010 May;255(2):613-21.

87. Benoist G, Salomon LJ, Jacquemard F, Daffos F, Ville Y. The prognostic value of ultrasound abnormalities and biological parameters in blood of fetuses infected with cytomegalovirus. BJOG Int J Obstet Gynaecol. 2008 Jun;115(7):823-9.

88. Leruez-Ville M, Stirnemann J, Sellier Y, Guilleminot T, Dejean A, Magny J-F, et al. Feasibility of predicting the outcome of fetal infection with cytomegalovirus at the time of prenatal diagnosis. Am J Obstet Gynecol. 2016 Sep;215(3):342.e1-9.

89. Romanelli RM de C, Magny JF, Jacquemard F. Prognostic markers of symptomatic congenital cytomegalovirus infection. Braz J Infect Dis Off Publ Braz Soc Infect Dis. 2008 Feb;12(1):38-43.

90. Enders G, Bader U, Lindemann L, Schalasta G, Daiminger A. Prenatal diagnosis of congenital cytomegalovirus infection in 189 pregnancies with known outcome. Prenat Diagn. 2001 May;21(5):362-77.

91. Leruez-Ville M, Ghout I, Bussieres L, Stirnemann J, Magny J-F, Couderc S, et al. In utero treatment of congenital cytomegalovirus infection with valacyclovir in a multicenter, open-label, phase II study. Am J Obstet Gynecol. 2016 Oct;215(4):462.e1-462.e10.

92. Revello MG, Lazzarotto T, Guerra B, Spinillo A, Ferrazzi E, Kustermann A, et al. A randomized trial of hyperimmune globulin to prevent congenital cytomegalovirus. N Engl J Med. 2014 Apr 3;370(14):1316-26.

93. Shahar-Nissan K, Pardo J, Peled O, Krause I, Bilavsky E, Bilavsky E, et al. LB20. Valacyclovir to Prevent Vertical Transmission of Cytomegalovirus After Maternal Primary Infection During Pregnancy. Open Forum Infect Dis [Internet]. 2019 Oct 23 [cited 2020 Apr 27];6(Suppl 2):S1002. Available from: https://www.ncbi.nlm.nih.gov/pmc/articles/PMC6810863/

94. Kagan KO, Enders M, Schampera MS, Baeumel E, Hoopmann M, Geipel A, et al. Prevention of maternal-fetal transmission of cytomegalovirus after primary maternal infection in the first trimester by biweekly hyperimmunoglobulin administration. Ultrasound Obstet Gynecol [Internet]. 2019 Mar 1 [cited 2020 Jan 15];53(3):383-9. Available from: https://obgyn-onlinelibrary-wileycom.sirius.parisdescartes.fr/doi/full/10.1002/uog.19164

95. Rubella [Internet]. [cited 2020 Apr 28]. Available from: https://www.who.int/news-room/factsheets/detail/rubella

96. Maternal rubella and the congenital rubella syndrome. - PubMed - NCBI [Internet]. [cited 2020 Apr 28]. Available from: https://www-ncbi-nlm-nihgov.sirius.parisdescartes.fr/pubmed/?term $=$ Maternal + rubella + and + the+congenital + rubella + syndrome.+ Clin + Perinatol +

97. Rubella | German Measles | Home | CDC [Internet]. 2019 [cited 2020 Apr 28]. Available from: https://www.cdc.gov/rubella/index.html

98. Miller E, Cradock-Watson JohnE, Pollock ThomasM. CONSEQUENCES OF CONFIRMED MATERNAL RUBELLA AT SUCCESSIVE STAGES OF PREGNANCY. The 
Lancet [Internet]. 1982 Oct 9 [cited 2020 Apr 28];320(8302):781-4. Available from: http://www.sciencedirect.com/science/article/pii/S0140673682926770

99. Bukasa A, Campbell H, Brown K, Bedford H, Ramsay M, Amirthalingam G, et al. Rubella infection in pregnancy and congenital rubella in United Kingdom, 2003 to 2016. Eurosurveillance [Internet]. 2018 May 10 [cited 2020 Apr 27];23(19):17-00381. Available from: https://www.eurosurveillance.org/content/10.2807/1560-7917.ES.2018.23.19.17-00381

100. Marchi S, Viviani S, Montomoli E, Trombetta CM. Elimination of congenital rubella: a seroprevalence study of pregnant women and women of childbearing age in Italy. Hum Vaccines Immunother [Internet]. 2020 Apr 2 [cited 2020 Apr 28];16(4):895-8. Available from: https://doi.org/10.1080/21645515.2019.1688041

101. Zhang HJ, Patenaude V, Abenhaim HA. Maternal outcomes in pregnancies affected by varicella zoster virus infections: Population-based study on 7.7 million pregnancy admissions. J Obstet Gynaecol Res [Internet]. 2015 Jan 1 [cited 2020 Apr 29];41(1):62-8. Available from: https://obgyn-onlinelibrary-wileycom.sirius.parisdescartes.fr/doi/full/10.1111/jog.12479

102. Paryani SG, Arvin AM. Intrauterine Infection with Varicella-Zoster Virus after Maternal Varicella. N Engl J Med [Internet]. 1986 Jun 12 [cited 2020 Apr 29];314(24):1542-6. Available from: https://doi.org/10.1056/NEJM198606123142403

103. Pastuszak AL, Levy M, Schick B, Zuber C, Feldkamp M, Gladstone J, et al. Outcome after Maternal Varicella Infection in the First 20 Weeks of Pregnancy [Internet]. $\quad$ http://dx.doi.org.sirius.parisdescartes.fr/10.1056/NEJM199403313301305. Massachusetts Medical Society; 2010 [cited 2020 Apr 29]. Available from: https://wwwnejm-org.sirius.parisdescartes.fr/doi/10.1056/NEJM199403313301305?url_ver=Z39.88-2003\&rfr_id=ori\%3Arid\%3Acrossref.org\&rfr_dat=cr_pub\%3Dwww.ncbi.nlm.nih.gov

104. Fetal varicella syndrome - ScienceDirect [Internet]. [cited 2020 Apr 29]. Available from: https://wwwsciencedirect-com.sirius.parisdescartes.fr/science/article/pii/S002234768780447X?via\%3Dihub

105. Prevention of Varicella: Recommendations of the Advisory Committee on Immunization Practices (ACIP) [Internet]. [cited 2020 Apr 29]. Available from: https://www.cdc.gov/mmwr/preview/mmwrhtml/00042990.htm

\section{Hosted file}

Table \& Figure.docx available at https://authorea.com/users/309007/articles/450363-maternalinfections-revisiting-the-need-for-screening-in-pregnancy 